\title{
PEMANFAATAN LAHAN PADA AREAL TANAM KELAPA SAWIT BELUM MENGHASILAKN (TBM) DENGAN MEBUDIDAYAKAN KACANG TANAH
}

\author{
MITHA SUGIS RIDAENY ( 1554201021 ) \\ PRODI AGRIBISNIS, FAKULTAS PERTANIAN \\ UNIVERSITAS LANCANG KUNING RIAU
}

\begin{abstract}
ABSTRAK
Artikel ini membahas tentang pemanfaatan areal tanam kelapa sawit belum menghasilkan dengan membudidayakan tanaman kacang tanah. Yang menjadi sasarannya adalah petani dengan jumlah lahan terbatas. Agar pendapatan mereka tetap ada selama selang waktu berbuahnya kelapa sawit dengan memproduksi kacang tanah. Selain bisa membantu penghasilan, kacang tanah juga baik untuk unsur hara tanah guna pertumbuhan kelapa sawit.
\end{abstract}

Kata kunci: tumpang sari, kelapa sawit, kacang tanah

\section{PENDAHULUAN}

Salah satu contoh tanaman perkebunan yang menjadi primadona di kalangan petani perkebunan adalah tanaman kelapa sawit. Tanaman ini penghasil minyak masak, minyak industri dan bahan bakar. Perkebunannya menghasilkan keuntungan yang sangat besar sehingga banyak hutan maupun perkebunan lama di konversikan keperkebunan kelapa sawit. Dalam proses penanaman biasanya petani yang hanya memiliki luas lahan terbatas akan memiliki kendala karena benih kelapa sawit berupa kecambah. Waktu yang diperlukan untuk bibitan hingga berumur 8 bulan. Pada usia ini sebenarnya bibit sudah dapat dipindahkan ke areal penanaman, tetapi umumnya bibit dipindah ke lapangan pada umur 10-14 bulan, jarak dari pemindahan bibit kelapa sawit ke areal tanam sampai menghasilkan buah memerlukan waktu sekitar 2-3 tahun. 
Selama selang waktu tersebut petani bisa membudidayakan tanaman lain dengan pola tanam tumpang sari.

Tumpang sari merupakan suatu pola tanam campuran yang terdiri dari dua atau lebih jenis tanaman pada satu lahan yang sama dan dalam waktu yang bersamaan. Tujuan dilakukannya pola tanam tumpang sari ini untuk mendapatkan produksi yang maksimal dengan kondisi lahan yang minimal.

\section{TINJAUAN PUSTAKA}

Tumpangsari kelapa sawit memiliki beberapa kelebihan yaitu: mengoptimalkan pemanfaatan lahan yang ditujukan oleh nisbah kesetaraan lahan (NKL) atau land equivalent ratio (LER), menghasilkan produk yang beragam, memperoleh hasil tambahan, memperbaiki kesuburan tanah dan mencegah erosi. (Nengsih 2016).

Lahan di bawah budidaya tanaman jagung manis berpotensi untuk digunakan dalam membudidayakan tanaman pangan lain. Hal ini merupakan salah satu bentuk efisiensi penggunaan lahan pertanian, karena pada saat ini kepemilikan lahan pertanian oleh petani semakin terbatas. Sistem tumpangsari merupakan solusi yang dapat digunakan oleh petani dalam mengelola lahan pertaniannya. (Surtinah, Susi and Lestari, Optimasi Lahan dengan Sistem Tumpang Sari Jagung Manis (Zea mays saccharata, Sturt) dan Kangkung Sutra (Ipomea reptans) 2015)

Hasil jagung manis yang ditanam secara monokultur maupun dengan sistem tumpangsari berbeda tidak nyata untuk semua parameter. Hal ini berarti bahwa tanaman kangkung yang berada di bawah tanaman jagung manis tidak mempengaruhi hasil jagung manis. (Surtinah, Susi and Lestari, Optimasi Lahan dengan Sistem Tumpang Sari Jagung Manis (Zea mays saccharata, Sturt) dan Kangkung Sutra (Ipomea reptans) 2015)

Tanaman melon merupakan tanaman dengan klasifikasi fisiologisnya adalah tanaman C3. Tanaman C3 merupakan tanaman yang akan mengalami fotorespirasi yang besar bila berada pada kondisi intensitas cahaya yang tinggi. Hal ini juga merupakan salah satu penyebab yang 
mengakibatkan tanaman stress. (Surtinah, Evaluasi Deskriptif Umur Panen Melon (Cucumis melo, L) 2017).

Kacang tanah adalah komoditas agribisnis yang bernilai ekonomi cukup tinggi dan merupakan salah satu sumber protein dalam pola pangan penduduk Indonesia. Kebutuhan kacang tanah dari tahun ke tahun terus meningkat sejalan dengan bertambahnya jumlah penduduk, kebutuhan gizi masyarakat, diversifikasi pangan, serta meningkatnya kapasitas industri pakan dan makanan di Indonesia. (Adisarwanto 2000)

Pada umumnya tanaman kacang tanah mempunyai arti penting dalam menambah kesuburan tanah karena kemampuannya mengikat $\mathrm{N}$ dari atmosfir sebagai hasil kerja sama dengan bakteri Rhizobium sp dalam bintil akar. Manfaat $\mathrm{N}$ fiksasi bagi tanaman lain dapat berupa perembesan dari bintil akar untuk tanaman yang tumbuh bersama tanaman leguminosa, dan perombakan bahan organik untuk tanaman berikutnya. (Brady 1982)

\section{HASIL DAN PEMBAHASAN}

Kelapa sawit merupakan tumbuhan yang lahan perkebunannya bisa ditanami berdampingan dengan tanaman-tanaman jenis lainnya. Luas areal perkebunan memungkinkan untuk berbagi lahan dengan tanaman tumpang sari agar lahan yang luas tersebut tidak di tanami oleh gulma. Ini sejalan dengan penelitian dengan kutipan "Lahan di bawah budidaya tanaman jagung manis berpotensi untuk digunakan dalam membudidayakan tanaman pangan lain. Hal ini merupakan salah satu bentuk efisiensi penggunaan lahan pertanian, karena pada saat ini kepemilikan lahan pertanian oleh petani semakin terbatas. Sistem tumpangsari merupakan solusi yang dapat digunakan oleh petani dalam mengelola lahan pertaniannya". (Surtinah, Susi and Lestari, Optimasi Lahan dengan Sistem Tumpang Sari Jagung Manis (Zea mays saccharata, Sturt) dan Kangkung Sutra (Ipomea reptans) 2015) luas areal tanam jagung tidak menghabiskan luasan yang banyak tetapi masih bisa di manfaatkan, terlebih lagi areal tanam kelapa sawit, sangat menguntungkan bila dapat dimanfaatkan dengan budidaya tanaman lain.

Pada saat awal pembukaan lahan, penanaman kelapa sawit membutuhkan waktu yang panjang untuk bisa menikmati hasilnya. Asal kelapa sawit berawal dari benih yang 
dikecambahkan. Kecambah kelapa sawit di tanam di bibitan hingga 8 bulan, tetapi petani lebih memilih 12-14 bulan untuk pemindahan ke areal tanam. Karena ada alasan lingkungan seperti gangguan hama babi dan lain sebagainya. Setelah pemindahan ke areal tanam memerlukan 2 sampai 3 tahun untuk mulai berproduksi. Pada selang waktu penanaman awal hingga kelapa sawit berproduksi adalah masalah yang di alami petani karena luas lahan terbatas, sementara setiap waktu harus memenuhi kebutuhan keluarganya.

Membudidayakan tanaman lain di areal tanaman kelapa sawit yang belum menghasilkan adalah salah satu cara untuk meningkatkan hasil produksi dan pendapatan petani. Selain dari fungsi ekonomi, pola tanam tumpang sari memiliki fungsi lainnya seperti menambah unsur organic dalam tanah dan menjaga keseimbangan unsur hara pada tanah. Dengan pola tanam tumpang sari ini ytidak akan mempengaruhi produktifitas tanaman utamanya, ini di dukung dengan pernyataan surtinah dalam tumpang sari jagung manis dan melonnya "Hasil jagung manis yang ditanam secara monokultur maupun dengan sistem tumpangsari berbeda tidak nyata untuk semua parameter. Hal ini berarti bahwa tanaman kangkung yang berada di bawah tanaman jagung manis tidak mempengaruhi hasil jagung manis." (Surtinah, Susi and Lestari, Optimasi Lahan dengan Sistem Tumpang Sari Jagung Manis (Zea mays saccharata, Sturt) dan Kangkung Sutra (Ipomea reptans) 2015)

Salah satu jenis tanaman yang cocok di tumpang sarikan dengan kelapa sawit adalah jenis kacang-kacangan. Tanaman kacang-kacangan merupakan tanaman dengan klasifikasi fisiologisnya adalah tanaman C3. Tanaman C3 merupakan tanaman yang akan mengalami fotorespirasi yang besar bila berada pada kondisi intensitas cahaya yang tinggi. Hal ini juga merupakan salah satu penyebab yang mengakibatkan tanaman stress. (Surtinah, Evaluasi Deskriptif Umur Panen Melon (Cucumis melo, L) 2017). Ini mendukung system tanam tumpang sari, sebagai ganti naungan untuk melindungi tanaman C3 dari intensitas cahaya matahari adalah tanaman kelapa sawit. Karena konsepnya tanaman C3 membutuhkan naungan.

Kacang-kacangan seperti kacang tanah dan beberapa jenis kacang lainnya dapat membantu dengan baik di perkebunan kelapa sawit, contohnya sebagai tumbuhan yang memberikan nitrogen dan membantu perkembangan bakteri baik yang berguna untuk tanaman inti. Bakteri tersebut bernama Rhizobium (yang terkenal yaitu Rhizobium leguminosarum) adalah 
bakteri baik tersebut merupakan penghuni biasa didalam tanah, Bakteri ini masuk melalui bulubulu akar tanaman kacang kacangan dan menyebabkan jaringan lebih banyak tumbuh hingga menjadi kutil-kutil diakar. Bakteri ini hidup dalam sel-sel akar dan memperoleh makanannya dari sel-sel tersebut, mampu mengikat nitrogen bebas dari udara dan mengubahnya menjadi suatu senyawa yang dapat diserap oleh tumbuhan. Karena kemampuannya mengikat nitrogen di udara, bakteri-bakteri tersebut berpengaruh terhadap nilai ekonomi tanah pertanian.

Kacang tanah akan tumbuh baik pada tekstur tanah yang remah dan jarak tanam dari kelapa sawit sendiri yang berjauhan tidak menghawatirkan tanaman kacang tanah kekurangan sinar matahari. Usia kacang tanah sampai pemanenan bervariasi tergantung varietas yang digunakan, usia pendek berkisar 3-4 bulan dan usia panjang 5-6 bulan. Untuk produksi per Ha kacang tanah berada pada angka 1,5 sampai 2,5 ton. Populasi kacang tanah pada luasan tanam kelapa sawit hanya berkisar 50-75\% saja dari luasan lahan sesungguhnya, berbansing terbalik dengan penelitian surtinah pada tumpang sari jagung manisnya, tetapi itu sudah sangat membantu petani karena tidak menyianyiakan lahan yang bisa di manfaatkan untuk tanaman lain, dan waktu hingg 3 tahun untuk menunggu kelapa sawit mulai berproduksi. Karena prioritasnya untuk pemanfaatan lahan.

\section{KESIMPULAN}

Tanaman perkebunan mampu ditumpangsarikan dengan tanaman semusim. Selain untuk pemanfaatan lahan, fungsinya pola tanam tumpang sari memaksimalkan produksi dengan meminimalkan lahan. Tanaman kelapa sawit pada fase pemindahan hingga berproduksi dapat diselingi dengan budidaya kacang tanah, untuk membantu penghasilan petani yang hanya memiliki lahan terbatas. Hasil produksi kacang tanah yang didapat hanya berkisar 50-75\% per hektar dari hasil produksi sesungguhnya, karena di tumpang sarikan dengan kelapa sawit. 


\section{DAFTAR PUSTAKA}

Adisarwanto. Meningkatkan Produksi Kacang Tanah di Lahan Sawah dan Lahan Kering. Jakarta: Penebar Swadaya, 2000.

Brady, Buckman H.O dan N.C. "Ilmu Tanah." Bhratara Karya Aksara, 1982: 788.

Nengsih, Yulistiati. "Tumpang Sari Tanaman Kelapa Sawit (Elaeis guineensis Jacq.) dengan Tanaman Karet (Hevea brassiliensis L.)." Media Pertanian (Jurnal Media Pertanian) 1 No 2 (2016): 66-77.

Surtinah. "Evaluasi Deskriptif Umur Panen Melon (Cucumis melo, L)." Jurnal Ilmiah Pertanian 14 No.1 (Agustus 2017): 69.

Surtinah, Neng Susi, and Sri Utami Lestari. "Optimasi Lahan dengan Sistem Tumpang Sari Jagung Manis (Zea mays saccharata, Sturt) dan Kangkung Sutra (Ipomea reptans)." 2015.

Surtinah, Neng Susi, and Sri Utami Lestari. "Optimasi Lahan dengan Sistem Tumpang Sari Jagung Manis (Zea mays saccharata, Sturt) dan Kangkung Sutra (Ipomea reptans)." 2015. 